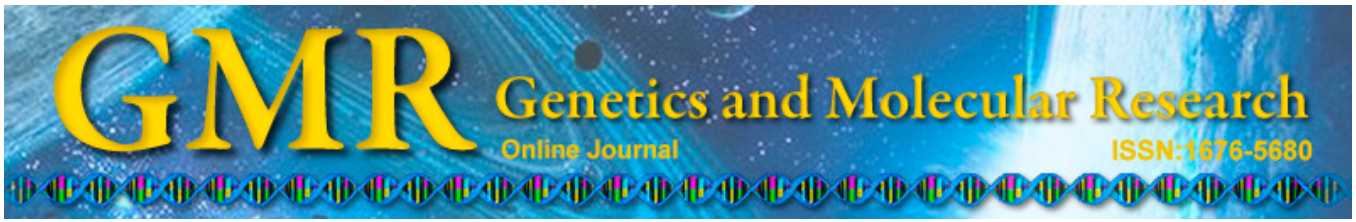

\title{
Isolation and characterization of microsatellite loci for Cunninghamia lanceolata (Lamb.) Hook
}

\author{
Y.X. Li ${ }^{1,2,3 *}$, Z.S. Wang ${ }^{1,2,3 *}$, J.K. Sui ${ }^{1,2,3}$, Y.F. Zeng ${ }^{1,2,3}$, A.G. Duan ${ }^{1,2,3}$ and \\ J.G. Zhang ${ }^{1,2,3}$
}

${ }^{1}$ State Key Laboratory of Tree Genetics and Breeding, Research Institute of Forestry, Chinese Academy of Forestry, Beijing, China ${ }^{2}$ Collaborative Innovation Center of Sustainable Forestry in Southern China, Nanjing Forestry University, Nanjing, China

${ }^{3}$ Key Laboratory of Tree Breeding and Cultivation, State Forestry Administration, Research Institute of Forestry, Chinese Academy of Forestry, Beijing, China

*These authors contributed equally to this study. Corresponding authors: A.G. Duan / J.G. Zhang E-mail: duanag@163.com / zhangjg@caf.ac.cn

Genet. Mol. Res. 14 (1): 453-456 (2015)

Received January 2, 2014

Accepted March 20, 2014

Published January 23, 2015

DOI http://dx.doi.org/10.4238/2015.January.23.19

ABSTRACT. As a result of human activities, wild populations of Cunninghamia lanceolata (Cupressaceae) have sharply declined in recent years. The development and implementation of a valid conservation strategy require a clear understanding of the genetic makeup of this species. Eleven polymorphic microsatellite loci were isolated and characterized from samples of 52 individuals from the Provenance Test Plantation in Fenyi, Jiangxi Province, China. Among the loci, 10 were polymorphic and 1-34 (average 18.182) alleles per locus were identified. Observed and expected heterozygosities ranged from 0 to 0.750 (mean 0.456 ) and 0 to 0.968 (mean 0.749), respectively. These microsatellite loci may facilitate further research on the molecular breeding and population genetics of C. lanceolata and its relatives.

Key words: Cunninghamia lanceolata; Cupressaceae; Microsatellites; Genetic conservation; Population genetics 


\section{INTRODUCTION}

Cunninghamia lanceolata (Lamb.) Hook is one of the most important commodities in the timber tree industry because of its fast growth, good material, high yield, and wide use (Shi et al., 1993; Yang et al., 2009); moreover, it is widely cultivated in southern China. As a result of human overexploitation of natural populations, wild populations of $C$. lanceolata have sharply declined (Lu et al., 2001). Understanding the genetic structure of a population of C. lanceolata will set the foundation for the conservation and utilization of important wild genetic resources. Nevertheless, research on the genetic structure of a population has been impeded because of the lack of high polymorphic genetic markers. Herein, we report a set of high-polymorphic novel microsatellite loci developed specifically for $C$. lanceolata, which will facilitate the exploration of the population genetics and genetic enhancement of $C$. lanceolata.

\section{MATERIAL AND METHODS}

\section{Biological material}

The biological material was sampled from the Provenance Test Plantation located in Fenyi, Jiangxi Province, China, in 2012, which was constructed in 1981 with seeds collected throughout the country (Duan et al., 2013). The fresh leaves were collected and immediately stored on silica gel. A specimen of this species was deposited in the Key Laboratory of Tree Breeding and Cultivation of the State Forestry Administration, Research Institute of Forestry, Chinese Academy of Forestry.

\section{DNA isolation and marker procedure}

Complete genomic DNA was extracted from silica gel-dried leaves using the modified cetyltrimethylammonium bromide (CTAB) procedure (Doyle, 1987).

Total DNA was digested with RsaI and XmnI (New England Biolabs, Ipswich, MA, USA) at $37^{\circ} \mathrm{C}$ for $12 \mathrm{~h}$. The digested DNA was linked to a double-strand Super SNX-24 linker (reverse: 5'-pGAT TCT GCT AGC TAG GCC TTA AAC AAA-3'; forward: 5'-GTT TAA GGC CTA GCT AGC AGA ATC- $3^{\prime}$ ) at $4^{\circ} \mathrm{C}$ for $12 \mathrm{~h}$. The ligated DNA was then randomly hybridized with 2 single-strand biotinylated microsatellite probes [5'-(CA) $)_{15}$-Biotin and 5 '-(GA) $)_{15}$-Biotin]. Hybridized DNA was captured by streptavidin-coated paramagnetic beads (Dynal Biotech Dynabeads M-280 Streptavidin, Oslo, Norway) and collected with a magnetic particle-collecting unit (MPC, Dynal Biotech Dynal MPC-S, Dynal, Oslo, Norway). The enriched DNA was amplified with superSNX-24 linker-forward as a primer, and the purified polymerase chain reaction (PCR) products were ligated into the pGEM-T Easy vector (Promega Corp., Madison, WI, USA) and then transformed into Escherichia coli (TransGen Biotech, Beijing, China) TOP10 cells.

In total, 120 positive colonies were randomly selected for sequencing using the $\mathrm{ABI}$ 3730XL DNA analyzer (Applied Biosystems, Foster City, CA, USA); a total of 80 (66.67\%) sequences contained repeat motifs. Of the sequences, 65 were selected for primer design with Primer premier 5.0 (Premier Biosoft International, Silicon Valley, CA, USA). Finally, 11 primer pairs (Table 1) were chosen because of their clear single bands of expected size. 


\section{Amplification and sequencing}

The forward primer of each primer pair was labeled with one of the 2 fluorescent dyes (i.e, FAM or HEX) at the 5'-end. PCR was performed in 10- $\mu \mathrm{L}$ reactions containing 5-50 ng template DNA, $0.4 \mu \mathrm{L} 10 \mu \mathrm{M}$ of each primer, $1 \mu \mathrm{L}$ 10X PCR buffer (Mg ${ }^{2+}$ Plus), $0.8 \mu \mathrm{L} 2.5 \mathrm{mM}$ dNTP mixture, and $0.05 \mu \mathrm{L} 5 \mathrm{U} / \mu \mathrm{L}$ rTaq DNA polymerase (TaKaRa, Dalian, Liaoning, China). The reactions were then placed in a temperature gradient $96 \mathrm{U}$ thermocycler (Applied Biosystems).

PCR was performed using an initial denaturation step at $94^{\circ} \mathrm{C}$ for $5 \mathrm{~min}$, followed by 30 cycles of denaturation at $94^{\circ} \mathrm{C}$ for $30 \mathrm{~s}$, annealing at a specific temperature for each locus (optimized for each locus; Table 1) for $30 \mathrm{~s}$, extension at $72^{\circ} \mathrm{C}$ for $70 \mathrm{~s}$, and a final extension at $72^{\circ} \mathrm{C}$ for $8 \mathrm{~min}$. PCR products were screened on an ABI 3130xl genetic analyzer with the GeneScan LIZ500 size standard (Applied Biosystems).

\section{Data analysis}

Microsatellite profiles were analyzed with the aid of GeneMapper v4.0 (Applied Biosystems). The $N_{\mathrm{A}}, H_{\mathrm{O}}$, and $H_{\mathrm{E}}$ were calculated using Arlequin v3.0 (Excoffier et al., 2005).

\section{RESULTS}

In total, 10 of the 11 loci displayed polymorphisms, and the number of alleles per locus ranged from 1 to 34 , with an average of 18.182 per locus. The $H_{\mathrm{O}}$ and $H_{\mathrm{E}}$ per locus ranged from 0 to 0.750 and 0 to 0.968 , respectively (Table 1). All the DNA sequences in this study are available under GenBank accession Nos. KF873003-KF873013.

\begin{tabular}{|c|c|c|c|c|c|c|c|c|}
\hline Locus & Primers $\left(5^{\prime}-3^{\prime}\right)$ & $\begin{array}{c}\text { Repeat } \\
\text { motif }\end{array}$ & $\begin{array}{l}\text { Size range } \\
\text { (bp) }\end{array}$ & $\begin{array}{l}\mathrm{Ta} \\
\left({ }^{\circ} \mathrm{C}\right)\end{array}$ & $N_{\mathrm{A}}$ & $H_{\mathrm{O}}$ & $H_{\mathrm{E}}$ & $\begin{array}{c}\text { GenBank } \\
\text { accession No. }\end{array}$ \\
\hline SM19 & $\begin{array}{l}\text { F: CACTTTGAATACGGTGCCTTTG } \\
\text { R: CACGCAACCAAAACATGTAAAA }\end{array}$ & $(\mathrm{TG})_{8}$ & 223-241 & 57 & 6 & 0.385 & 0.604 & KF873006 \\
\hline SM37 & $\begin{array}{l}\text { F: TAGGGTGAAAGGAGGATTTTGACAT } \\
\text { R: ACATAGAGTGAGTGCCAATGCTCAT }\end{array}$ & $(\mathrm{TG})_{13}$ & $345-397$ & 66 & 17 & 0.462 & 0.878 & KF873008 \\
\hline SM2 & $\begin{array}{l}\text { F: CTCATCATTCTTGAACCCATCC } \\
\text { R: AACCTGACCAATCCTTGCTCT }\end{array}$ & $(\mathrm{GT})_{9}$ & $231-259$ & 58 & 16 & 0.750 & 0.874 & KF873003 \\
\hline SM51 & $\begin{array}{l}\text { F: TCCTCTATCTTGTCAGTTTGGGTT } \\
\text { R: TATTGGTGTTGCTCGTCATTCC }\end{array}$ & $(\mathrm{AC})_{12}$ & 291-303 & 66 & 6 & 0.442 & 0.511 & KF873009 \\
\hline SM14 & $\begin{array}{l}\text { F: ATTTTCATTTTGAAGATCATCCGC } \\
\text { R: CTTGTTTGGGTTTTGTTCTTCATC }\end{array}$ & $(\mathrm{AC})_{33}$ & 244-327 & 60 & 34 & 0.673 & 0.968 & KF873005 \\
\hline SM13 & $\begin{array}{l}\text { F: TCGTGAGTTTCTTGGTCATTTCG } \\
\text { R: CATAAGGGTTTTCCCCACGTATA }\end{array}$ & $(\mathrm{AG})_{8}$ & 389-395 & 61 & 6 & 0.404 & 0.603 & KF873004 \\
\hline XSM22 & $\begin{array}{l}\text { F: AGATAGTTCTCCCAGGCTATCCAAGAT } \\
\text { R: CCACCTACATACAACATAAGCGACCAA }\end{array}$ & $(\mathrm{AG})_{33}$ & 207-289 & 69 & 31 & 0.596 & 0.961 & KF873007 \\
\hline SM53 & $\begin{array}{l}\text { F: CACATGAAGTGAATGCCAAAGTTA } \\
\text { R: TTCCAGATAGTGTTGAATGGGGTA }\end{array}$ & $(\mathrm{CA})_{6}$ & 354 & 62 & 1 & 0 & 0 & KF873010 \\
\hline XSM8 & $\begin{array}{l}\text { F: TCAGGGCATTTGAAACGAATAG } \\
\text { R: TCAAGTGGGAGATTGTTGGGTA }\end{array}$ & $(\mathrm{CA})_{28}$ & $412-461$ & 58 & 25 & 0.692 & 0.926 & KF873011 \\
\hline XSM24 & $\begin{array}{l}\text { F: TTTCCCCTTAATGAACTTGTCTT } \\
\text { R: ATTCAGATGGAGGCAACAGAG }\end{array}$ & $(\mathrm{CT})_{27}$ & $272-367$ & 57 & 32 & 0.288 & 0.967 & KF873013 \\
\hline SM9 & $\begin{array}{l}\text { F: TAGTGGCAAAGAAGGGAGAAAGG } \\
\text { R: TGGTCTAAAAGTGCAAGTTGAGGA }\end{array}$ & $(\mathrm{GT})_{41}$ & $256-334$ & 63 & 26 & 0.327 & 0.953 & KF873012 \\
\hline Average & & & & & 18.182 & 0.456 & 0.749 & \\
\hline
\end{tabular}

$\mathrm{Ta}=$ annealing temperature. 


\section{CONCLUSIONS}

As high-resolution and codominant-inheritance genetic markers (Vendramin et al., 1996), microsatellite analysis is widely applied to population genetic studies. The 11 novel microsatellite loci developed herein will play an important role in further genetic studies, including population genetic diversity and differentiation, gene flow, and population demography of $C$. lanceolata.

\section{ACKNOWLEDGMENTS}

The authors are grateful to Dr. Zhang Xiongqing for the sampling of biological material. We also thank Du Shuhui for data analysis and suggestions on the preliminary vision of this paper. Research supported by the National Scientific and Technological Task for the 12th Five-Year Plan in China (\#2011AA100203) and Collaborative Innovation Plan of Jiangsu Higher Education.

\section{REFERENCES}

Doyle JJ (1987). A rapid DNA isolation procedure for small quantities of fresh leaf tissue. Phytochem. Bull. 19: 11-15.

Duan AG, Zhang JG, Zhang XQ and He CY (2013). Stand diameter distribution modelling and prediction based on Richards function. PloS One 8: e62605.

Excoffier L, Laval G and Schneider S (2005). Arlequin (version 3.0): an integrated software package for population genetics data analysis. Evol. Bioinform. Online 1: 47-50

Lu SY, Peng CI, Cheng YP, Hong KH, et al. (2001). Chloroplast DNA phylogeography of Cunninghamia konishii (Cupressaceae), an endemic conifer of Taiwan. Genome 44: 797-807.

Shi JS, Ye ZH, Hong JS, Yang RC, et al. (1993). Genetic diversity and multilocus structure in Chinese Fir. J. Nanjing Forestr. Univ. 17: 9-15.

Vendramin GG, Lelli L, Rossi P and Morgante M (1996). A set of primers for the amplification of 20 chloroplast microsatellites in Pinaceae. Mol. Ecol. 5: 595-598.

Yang YL, Ma XQ and Zhang MQ (2009). Molecular polymorphic analysis for different geographic provenances of Chinese fir. J. Trop. Subtropical Bot. 17: 183-189. 